\title{
MENINGKATKAN HASIL BELAJAR SISWA MELALUI MODEL PEMBELAJARAN CONTEXTUAL TEACHING AND LEARNING (CTL) PADA PELAJARAN PKN DI KELAS V SDN No.005 SIBARUANG
}

\author{
Anten Situmorang \\ Guru PKN di SD Negeri No. 005 Sibaruang \\ Surel: antensitumorang@yahoo.co.id
}

\begin{abstract}
ABSTRAK
Penelitian ini bertujuan untuk mengetahui hasil belajar siswa setelah menerapkan model pembelajaran Contextual Teaching And Learning (CTL) pada mata pelajaran PKn di kelas V SD Negeri 005 Sibaruang tahun pembelajaran 2013/2014. Subjek penelitian ini adalah seluruh siswa kelas V SDN No.005 Sibaruang dengan jumlah siswa 15 orang tahun pelajaran 2013/2014. Model pembelajaran Contextual Teaching And Learning (CTL) berdampak positif dalam meningkatkan aktivitas belajar siswa hal ini ditandai, yaitu pada siklus I aktivitas siswa yang paling dominan adalah menulis/membaca yaitu $36 \%$ mengalami penurunan menjadi $25 \%$ pada siklus II. Aktivitas mengerjakan LKS 22\% meningkat menjadi 37\%. Bertanya pada teman $12 \%$ meningkat menjadi $23 \%$. Bertanya pada guru $13 \%$ menurun menjadi $10 \%$. Yang tidak relepan dengan KBM 17\% menurun menjadi 5\%. Dari pretes diketahui hasil belajar rata-rata siswa 24 dengan nilai tertinggi 30 dan nilai terendah 10. Peningkatan hasil belajar siswa dari formatif siklus I dan formatif siklus II rata-rata 58,66 menjadi 85,3. Ketuntasan klasikal pada siklus I sebesar $26,66 \%$ dan pada siklus II sebesar $86,66 \%$.
\end{abstract}

Kata kunci : Hasil Belajar, Contextual Teaching And Learning

\section{PENDAHULUAN}

Proses pendidikan merupakan suatu sistem yang terdiri dari input, proses dan output. Input merupakan peserta didik yang akan melaksanakan aktivitas belajar, proses merupakan kegiatan dari belajar mengajar sedangkan output merupakan hasil dari proses yang akan dilaksanakan. Dari pelaksanaan proses pendidikan tersebut diharapkan dapat menghasilkan sumber daya manusia yang berkualitas dan berdaya saing yang tinggi untuk menghadapi persaingan di era globalisasi dewasa ini.

Peningkatan kualitas sumber daya manusia merupakan salah satu penekanan dari tujuan pendidikan, seperti yang tertuang dalam Undang Undang No. 20 Tahun 2003 tentang Sistem Pendidikan Nasional telah merumuskan secara tegas mengenai dasar, fungsi, dan tujuan Pendidikan Nasional. Pasal 2 Undang-Undang Nomor 20 Tahun 2003 tentang Sisten Pendidikan Nasional yang memuat dasar pendidikan Nasional, yaitu berdasar Pancasila dan UndangUndang Dasar 1945, sedang fungsinya yaitu mengembangkan kemampuan dan membentuk watak serta peradaban bangsa yang bermartabat dalam rangka mencerdaskan kehidupan bangsa. Pendidikan Nasional bertujuan untuk 
mengembangkan potensi peserta didik agar menjadi manusia yang beriman dan bertakwa kepada Tuhan Yang Maha Esa, berakhlak mulia, sehat, berilmu, cakap, kreatif, mandiri dan menjadi warga negara yang demokratis serta bertanggung jawab. Bertitik tolak dari dasar, fungsi, dan tujuan pendidikan nasional tersebut tampak jelas bahwa manusia yang berilmu pengetahuan semata tetapi sekaligus membentuk manusia Indonesia yang berkepribadian sebagai warga Negara Indonesia yang demokratis dan bertanggung jawab.

Berbagai usaha pembaharuan kurikulum, perbaikan sistem pengajaran, peningkatan kualitas kemampuan guru, pemilihan metode dalam mengajar, teknik mengajar dan penggunaan alat peraga atau media pembelajaran, merupakan suatu upaya ke arah meningkatkan keberhasilan pembelajaran. Dalam meningkatkan proses pembelajaran di sekolah, guru dituntut mampu merancang dan melaksanakan kegiatan pembelajaran yang dapat mengembangkan kemampuan kognitif, afektif dan psikomotorik siswa agar tercapai hasil belajar yang optimal. Oleh karena itu dalam mendesain kegiatan pembelajaran yang optimal diperlukan kecermatan guru memilih dan menerapkan serta menyusun strategi pembelajaran. Salah satunya dengan menerapkan pembelajaran Contextual Teaching and Learning (CTL).

Menurut Mohammad Jauhari (2011:182) CTL adalah "konsep belajar yang membantu guru mengaitkan antara materi pembelajaran dengan situasi dunia nyata siswa, dan mendorong siswa untuk membentuk hubungan antara pengetahuan yang dimilikinya dengan penerapannya dalam kehidupan mereka sehari-hari."

Sejalan dengan pendapat diatas, Wina Sanjaya (2002:87) juga berpendapat bahwa CTL adalah "suatu pendekatan pembelajaran yang menekankan kepada proses keterlibatan siswa secara penuh untuk menemukan materi yang dipelajari dan menghubungkannya dengan situasi nyata."

Dengan menggunakan model pembelajaran Contextual Teaching and Learning (CTL) maka pengetahuan yang diperoleh dapat tertanam dengan baik dan tidak mudah dilupakan oleh siswa karena saat menemukan suatu konsep mereka mengalami sendiri baik melalui proses mengamati, meraba, merasa, maupun bereksperimen. Metode ini juga akan menarik perhatian siswa karena siswa merasa dibawa langsung ke lingkungan yang telah akrab dengan kehidupannya.

Salah satu mata pelajaran yang dipelajari di Sekolah Dasar adalah Pendidikan Kewarganegaraan. Dalam kaitannya dengan pembentukan warga negara Indonesia yang demokratis dan bertanggung jawab, mata pelajaran Pendidikan Kewarganegaraan (PKn) memiliki peranan yang strategis dan penting, yaitu dalam membentuk pribadi siswa maupun sikap dalam 
berperilaku keseharian, sehingga diharapkan setiap individu mampu menjadi pribadi yang baik.

Melalui mata pelajaran PKn ini, diharapkan siswa sebagai warga negara dapat mengkaji dan memahami hak, kewajiban dan tanggung jawabnya sebagai warga negara. Berkaitan dengan tujuan pendidikan nasional, pembangunan dalam dunia pendidikan perlu ditingkatkan. Melalui pembelajaran PKn akan ditanamkan moral yang baik pada diri siswa dari sejak dini. Namum pada kenyataannya, sebagian siswa memandang mata pelajaran Pendidikan Kewarganegaraan sebagai mata pelajaran yang bersifat konseptual dan teoritis. Akibatnya siswa ketika menggikuti pembelajaran PKn merasa cukup mencatat dan menghafal konsep-konsep dan teoriteori yang dijelaskan oleh guru, tugas-tugas yang diberikan dikerjakan secara tidak serius dan bila dikerjakan pun sebatas formalitas.

Menciptakan situasi kelas yang inspiratif, interaktif, dan menyenangkan dalam pembelajaran PKn tidaklah mudah, karena sebagian besar siswa masih menganggap PKn sebagai pelajaran yang mementingkan hafalan. Pengetahuan yang diberikan guru dianggap kurang mendayagunakan potensi kognitif, afektif dan psikomotorik siswa secara optimal. Untuk mengubah anggapan tersebut, guru dituntut untuk dapat menciptakan suasana belajar yang lebih menekankan pada aktivitas belajar siswa dalam belajar.

Berdasarkan hasil observasi yang dilakukan peneliti di SDN No. 005 Sibaruang, bahwa dalam pelaksanaan guru cenderung menggunakan metode ceramah sehingga siswa pasif dan menimbulkan proses belajar yang monoton, kurang menarik dan hanya terpusat pada buku (teks book), hal ini berdampak pada hasil belajar siswa yang rendah. Guru juga tidak melibatkan siswa secara langsung sehingga suasana kelas menjadi bosan dan banyak siswa yang bermain pada saat proses pembelajaran berlangsung. Hal ini tentunya menyebabkan hasil belajar siswa sangat rendah pada pelajaran PKn. Ketidakberhasilan ini terlihat dari siswa di kelas V, yang memiliki hasil belajar dengan rata-rata dibawah $20 \%$. Nilai yang diharapkan adalah 70 ke atas namun ternyata hasil yang diperoleh masih banyak siswa yang mendapat nilai rendah di bawah rata-rata 70 . Berarti ketuntasan yang ditetapkan tidak seluruhnya diperoleh siswa sehingga dapat dikatakan hasil belajar siswa rendah. Kondisi semacam ini tentu tidak sejalan dengan semangat untuk menciptakan pembelajaran yang bermakna bagi siswa. Pembelajaran yang bersifat monoton dan masih menerapkan strategi maupun pendekatan pembelajran konvensional yang memandang siswa sebagai objek, komunikasi lebih banyak berlangsung searah, dan penilaian lebih menekankan aspek 
kognitif, maka tujuan pembelajaran tidak akan tercapai. Oleh karena itu guru perlu menciptakan suasana pembelajaran yang interaktif dan menyenangkan.

Setelah penulis mempelajari pembelajaran Contextual Teaching and Learning (CTL), penulis menganggap bahwa pembelajaran ini sesuai untuk mengajarkan siswa pada pelajaran PKn, karena siswa dapat berpikir dan memahami serta menerapkan dalam kehidupan seharihari. Dengan pembelajaran $C T L$ siswa akan bekerja dan mengalami bukan mentransfer pengetahuan dari guru ke siswa semata, tetapi dalam transfer belajar yang diharapkan, anak harus tahu makna belajar dan menggunakan pengetahuan serta keterampilan yang diperolehnya untuk memecahkan masalah dalam kehidupannya sehingga siswa akan memahami konsep suatu materi dan nantinya diharapkan siswa dapat menggunakan daya nalarnya untuk menyelesaikan masalah-masalah yang ada.

Berdasarkan uraian di atas penulis tertarik membuat suatu penelitian dengan judul "Meningkatkan Hasil Belajar Siswa Melalui Model Pembelajaran Contextual Teaching And Leanrning (CTL) Pada Mata Pelajaran PKn Di Kelas V SDN No.005 Sibaruang”.

Berdasarkan latar belakang masalah di atas identifikasi masalah dalam penelitian ini antara lain sebagai berikut :
1. Rendahnya tingkat penguasaan siswa terhadap materi pembelajaran PKn

2. Siswa kurang aktif dalam proses pembelajaran

3. Metode pembelajaran yang digunakan kurang efektif

4. Kemampuan siswa dalam mengaitkan pembelajaran dengan kehidupan sehari-hari masih rendah dan dibawah nilai ketuntasan minimal yaitu 70

5. Guru dominan menerangkan dengan berceramah pada saat pembelajaran

6. Pembelajaran PKn masih bersifat monoton, kurang menarik, dan terpusat pada buku (teks book)

Dari beberapa identifikasi masalah di atas, yang menjadi batasan masalah dalam penelitian ini adalah meningkatkan hasil belajar siswa dalam proses pembelajaran PKn dengan menggunakan model pembelajaran Contextual Teaching And Learning (CTL) pada siswa di kelas V SDN No.005 Sibaruang.

Berdasarkan uraian di atas maka rumusan masalah penelitian ini adalah : "Apakah dengan menggunakan model pembelajaran Contextual Teaching And Learning (CTL) dapat meningkatkan hasil belajar siswa pada mata pelajaran PKn di kelas V SDN No.005 Sibaruang?"

Adapun tujuan yang hendak dicapai dalam penelitian ini adalah untuk mengetahui Keefektifan menerapkan strategi CTL (Contextual Teaching And Learning) dapat meningkatkan hasil belajar 
siswa pada pelajaran PKn di SDN No.005 Sibaruang.

1. Bagi siswa

a. Menjadikan siswa untuk aktif dalam proses pembelajaran melalui model pembelajaran CTL.

b. Meningkatkan kemampuan siswa dalam mengaitkan mata pelajaran dengan kehidupan dan pengalaman sehari-hari

2. Bagi guru

a. Memberikan masukan kepada guru dalam mengajar dan mengembangkan keterampilan bertanya

b. Meningkatkan kemampuan mengajar guru

c. Umpan balik bagi guru untuk mengukur keberhasilan dalam pelaksanaan kegiatan belajar mengajar melalui Penelitian Tindakan Kelas.

d. Memberikan informasi kepada guru di SDN No. 005 Sibaruang mengenai pembelajaran CTL dalam meningkatkan hasil belajar siswa.

3. Bagi sekolah

a. Meningkatkan kualitas dan mutu sekolah khususnya pendidikan kewarganegaraan dengan menggunakan model pembelajaran $C T L$

b. Hasil penelitian ini diharapkan dapat sebagai umpan balik untuk meningkatkan efektivitas dan efisiensi pembelajaran.

c. Sebagai bahan masukan bagi sekolah untuk melakukan pembinaan terhadap guruguru, agar dapat menerapkan pembelajarn CTL dalam proses pembelajaran pada semua mata pelajaran

4. Bagi peneliti

a. Menambah pengetahuan dan pengalaman untuk mengembangkan ilmu pengetahuan dalam dunia pendidikan

\section{Definisi Operasional}

a) Model CTL dalam pembelajaran PKn merupakaan strategi pembelajaran yang mengaitkan materi pembelajaran secara alami dengan dunia nyata siswa sehingga dapat membuat hubungan antara siswa sebagai anggota keluarga masyarakat.

b) Hasil belajar adalah hasil pengukuran dari penilaian usaha belajar dan perubahan perilaku peserta didik yang diperoleh setelah mengikuti pembelajaran selama kurun waktu yang relatif menetap.

\section{METODE PENELITIAN}

\section{Tempat dan Waktu Penelitian}

Penelitian ini dilakukan di SDN No.005 Sibaruang Jalan Lintas Sumatera Medan-Padang, Desa Sibaruang Kecamatan Siabu, dan pelaksanaannya pada bulan Maret sampai dengan Juli 2014.

\section{Subjek Penelitian}

Subjek dalam penelitian ini adalah seluruh siswa kelas V SDN No.005 Sibaruang. Pemilihan kelas 
V dikarenakan peneliti merupakan guru kelas V SDN No.005 Sibaruang. Banyak subjek penelitian yakni 15 orang siswa.

\section{Alat Pengumpul Data}

Alat pengumpul data dalam penelitian ini antara lain:

a. Tes hasil belajar

Tes hasil belajar digunakan untuk mengetahui hasil belajar siswa sebelum dan sesudah pembelajaran dengan model pembelajaran Contextual Teaching and Learning $(C T L)$. Tes hasil belajar disusun dalam bentuk pilihan berganda yang mengacu pada Kurikulum Tingkat Satuan Pendidikan (KTSP) untuk kelas V SDN No.005 Sibaruang bidang studi PKn. Tes hasil belajar siswa yang digunakan sebanyak 10 item dan terdiri dari 4 opsion.

Kisi-kisi tes hasil belajar siswa tersebut dituangkan dalam bentuk Tabel spesifikasi seperti tercantum pada Tabel 3.1.

Tabel Tabel Kisi-Kisi Tes Hasil Belajar

\begin{tabular}{|c|c|c|c|c|c|}
\hline \multirow{2}{*}{ Butir Soal } & \multicolumn{4}{|c|}{ Klasifikasi / Kategori } & Jumlah \\
& $\mathrm{C}_{1}$ & $\mathrm{C}_{2}$ & $\mathrm{C}_{3}$ & $\mathrm{C}_{4}$ & soal \\
\hline 1 & & $\sqrt{ }$ & & & 1 \\
\hline 2 & & & & $\sqrt{ }$ & 1 \\
\hline 3 & & $\sqrt{ }$ & & & 1 \\
\hline 4 & & $\sqrt{ }$ & & & 1 \\
\hline 5 & & & $\sqrt{ }$ & & 1 \\
\hline 6 & & & & $\sqrt{ }$ & 1 \\
\hline 7 & & $\sqrt{ }$ & & & 1 \\
\hline 8 & & $\sqrt{ }$ & & & 1 \\
\hline 9 & & & $\sqrt{ }$ & & 1 \\
\hline 10 & & & & $\sqrt{ }$ & 1 \\
\hline Jumlah & 1 & 5 & 1 & 3 & 10 \\
\hline
\end{tabular}

Keterangan :

$\mathrm{C}_{1}$ : Pengetahuan

$\mathrm{C}_{2}$ : Pemahaman

$\mathrm{C}_{3}$ : Aplikasi

$\mathrm{C}_{4}$ : Analisis

b. Lembar Aktivitas Belajar Siswa

Lembar aktivitas belajar siswa digunakan oleh pengamat. Pengamat adalah guru-guru teman sejawat peneliti yaitu Ibu Tiasmari Gultom dan Ibu Nisfa. Waktu bekerja dalam kelompok peneliti/guru yang sedang melaksanakan kegiatan belajar mengajar (KBM) memberi isyarat pada ke dua pengamat, kelompok mana yang diamati oleh ke dua pengamat. Kedua pengamat tidak boleh duduk berdekatan agar data yang direkam tidak bias. Satu kali kegiatan pembelajaran yang dilakukan oleh peneliti, maka ada dua kelompok yang diamati oleh pengamat.

Instrumen aktivitas belajar siswa terdiri dari 5 aktivitas antara lain; membaca, bekerja, bertanya sesama siswa, bertanya sama guru, dan yang tidak relevan dengan KBM. Waktu siswa belajar sesuai dengan di RPP berkelompok selama 20 menit ditentukan oleh peneliti/guru maka ada 10 ceklis yang dilakukan oleh pengamat dalam lembar aktivitas belajar siswa.

\section{Rancangan Penelitian}

Penelitian ini menggunakan Penelitian Tindakan Kelas (PTK). PTK adalah suatu bentuk kajian yang bersifat reflektif oleh pelaku tindakan 
yang dilakukan untuk meningkatkan kemantapan rasional dari tindakan mereka dalam melaksanakan tugas, memperdalam pemahaman terhadap tindakan-tindakan yang dilakukan itu, serta memperbaiki kondisi dimana praktek pembelajaran tersebut dilakukan (dalam Mukhlis, 2000: 3).

Sesuai dengan jenis penelitian yang dipilih, yaitu penelitian tindakan kelas, maka penelitian ini menggunakan model penelitian tindakan dari Kemmis dan Taggart (dalam Sugiarti, 1997:6), yaitu berbentuk spiral dari sklus yang satu ke siklus yang berikutnya. Setiap siklus meliputi planning (rencana), action (tindakan), observation (pengamatan), dan reflection (refleksi).

Langkah pada siklus berikutnya adalah perencanaan yang sudah direvisi, tindakan, pengamatan, dan refleksi. Sebelum masuk pada siklus I dilakukan tindakan pendahuluan yang berupa identifikasi permasalahan. Siklus spiral dari tahap-tahap penelitian tindakan kelas dapat dilihat pada gambar berikut.
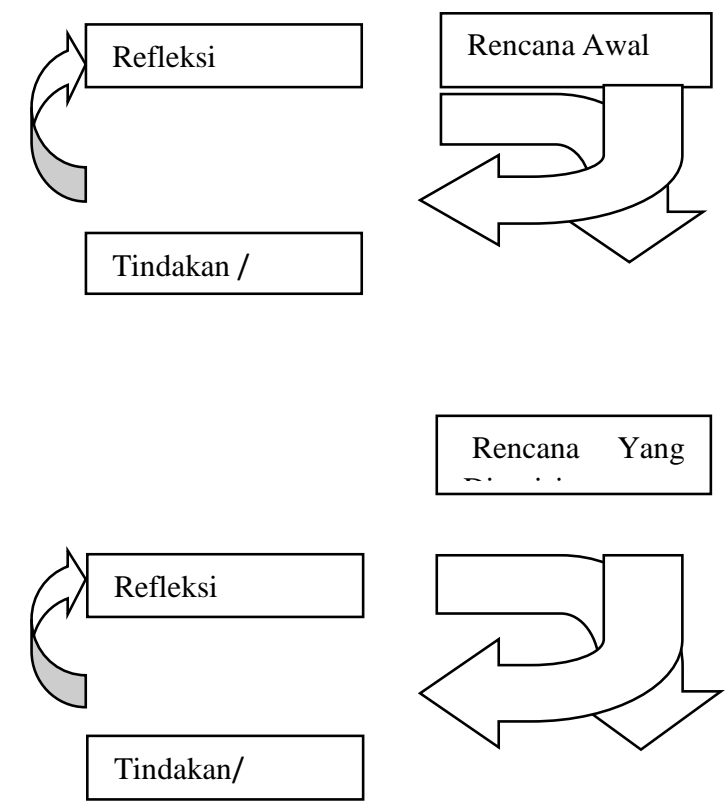

Rencana Yang Direvici

Gambar Penelitian Tindakan Model Kemmis dan Mc Taggart (Tim Pelatih Proyek PGSM, 1999 : 27)

\section{Prosedur Penelitian}

Berdasarkan informasi yang peneliti kumpulkan, bahwa hasil belajar siswa pada mata pelajaran PKn masih rendah yang diakibatkan rendahnya aktivitas belajar siswa, maka prosedur penelitian yang penulis rencanakan dalam menuntaskan hasil belajar tersebut adalah sebagai berikut :

\section{Siklus I}

Kegiatan pada siklus I meliputi:

1) Perencanaan Tindakan

Pada tahap ini peneliti membuat kegiatan perencanaan meliputi:

a) Penyusunan rencana pelaksanaan pembelajaran dan lembar kegiatan siswa untuk KBM 1 dan KBM 2. Selanjutnya diubah atau ditambah sesuai dengan 
model pembelajaran

Contextual Teaching and Learning (CTL).

b) Penyusunan instrumen penelitian berupa lembar observasi aktivitas siswa melalui penerapan model pembelajaran Contextual Teaching and Learning (CTL) dan tes pemahaman siswa.

2) Pelaksanaan Tindakan dan Observasi (Action and Observation)

Melaksanakan tindakan pembelajaran ke-1 dan ke-2 sesuai dengan RPP oleh peneliti sebagai guru PKn di kelas V SDN No.005 Sibaruang. Selama proses pembelajaran dilakukan observasi oleh observer (guru sejawat) untuk mengamati aktivitas siswa dan pengelolaan pembelajaran oleh guru. Diakhir siklus I dilakukan pula tes hasil belajar siswa untuk mengetahui pemahaman siswa sebagai formatif I.

3) Refleksi (Reflective)

Kegiatan refleksi dilakukan oleh peneliti berdasarkan hasil observasi dan evaluasi hasil pembelajaran PKn dengan model pembelajaran

Contextual

Teaching and Learning (CTL). Dari hasil refleksi kemudian peneliti dengan dua orang pengamat teman sejawat untuk memperbaiki dan menguatkan rencana tindakan siklus II.

\section{Siklus II}

Kegiatan pada Siklus II meliputi:

1) Perencanaan Tindakan

Berdasarkan hasil refleksi terhadap proses pembelajaran pada siklus I maka pada siklus II disusun skenario model pembelajaran Contextual Teaching and Learning (CTL) dengan revisi tindakan untuk memperbaiki proses. Peneliti berdiskusi secara kolaboratif dengan rekan guru kelas sejenis dengan kegiatan perencanaan meliputi:

c) Penyusunan rencana pelaksanaan pembelajaran dan lembar kegiatan siswa.

d) Penyusunan instrumen penelitian berupa lembar observasi aktivitas siswa serta pengelolaan guru terhadap proses pembelajaran dengan menerapkan model pembelajaran Contextual Teaching and Learning (CTL) dan tes pemahaman siswa dalam kegiatan pembelajaran

2) Pelaksanaan Tindakan dan Observasi (Action and Observation)

Melaksanakan tindakan pembelajaran ke-3 dan ke-4 sesuai dengan RPP strategi Contextual Teaching and Learning $(C T L)$ oleh peneliti sebagai guru PKn di Kelas V SDN No.005 Sibaruang. Selama proses pembelajaran dilakukan observasi oleh observer (guru 
sejawat) untuk mengamati aktivitas siswa. Diakhir siklus II dilakukan pula tes hasil belajar untuk mengetahui pemahaman kognitif siswa sebagai formatif II.

3) Refleksi (Reflective)

Setelah kegiatan pembelajaran siklus II dilaksanakan, dilanjutkan dengan kegiatan refleksi oleh peneliti berkolaborasi guru mata pelajaran sejenis. Berdasarkan hasil observasi aktivitas siswa dalam pembelajaran dan ketuntasan hasil belajar siswa ditelaah.

\section{Teknik Analisis Data}

Metode analisis data pada penelitian ini digunakan metode deskriptif dengan membandingkan hasil belajar siswa sebelum tindakan dengan hasil belajar siswa setelah tindakan.

Langkah-langkah pengolahan data sebagai berikut:

1) Merekapitulasi nilai pretes sebelum tindakan dan nilai tes akhir siklus I dan siklus II

2) Menghitung nilai rata-rata atau persentase hasil belajar siswa sebelum dilakukan tindakan dengan hasil belajar setelah dilakukan tindakan pada siklus I dan siklus II untuk mengetahui adanya peningkatan hasil belajar.

3) Penilaian

a. Data nilai hasil belajar (kognitif) diperoleh dengan menggunakan rumus:
Nilai Siswa $=\frac{\text { Jumlah jawaban benar }}{\text { Jumlah seluruh soal }} \times 100$

(Slameto,2001:189)

b. Nilai rata-rata siswa dicari dengan rumus sebagai berikut:

$$
\bar{X}=\frac{\sum X}{N}
$$

Keterangan :

$$
\begin{aligned}
& \bar{X}=\text { Nilai rata-rata } \\
& \Sigma=\text { Jumlah nilai } X \\
& \mathrm{~N}=\text { Jumlah peserta tes }
\end{aligned}
$$

c. Untuk penilaian aktivitas digunakan rumus sebagai berikut:

Setelah data aktivitas siswa terkumpul sesuai dengan jumlah kegiatan belajar mengajar, maka data tersebut disusun kemudian data tersebut dirubah menjadi data prosentase. Untuk menganalisis data-data tersebut kemudian dianalisis dengan proporsi aktivitas.

\% Proporsi Aktivitas $=\frac{\text { jumlah skor yang diperoleh }}{\text { jumlah skor ideal }} \times 100 \%$

(Majid, 2009:268)

d. Ketentuan persentase ketuntasan belajar kelas

Ketuntasan belajar kelas $=\frac{\sum S_{b}}{K} \times 100 \%$

$\Sigma \mathrm{Sb}=$ Jumlah siswa yang mendapat nilai $\geq 70$ (kognitif)

$\Sigma \mathrm{K}=$ Jumlah siswa dalam sampel

Sebagai tolak ukur keberhasilan penelitian tindakan kelas ini dapat dilihat dari hasil tes, jika hasil belajar siswa mencapai 
nilai $\geq 70$ maka disebut tuntas individu, dan bila ada $85 \%$ nilai $\geq$ 70 disebut tuntas kelas.

\section{Indikator Keberhasilan}

Yang menjadi $\begin{gathered}\text { indikator } \\ \text { mengajar }\end{gathered}$
keberhasilan guru
digunakan KKM mata pelajaran PKn
di SDN No.005 Sibaruang dengan
nilai $\geq 70$ maka disebut tuntas
individu, dan bila ada $85 \%$ nilai $\geq$
70 disebut tuntas kelas.

\section{HASIL PENELITIAN DAN PEMBAHASAN \\ Penyajian Data}

Sekolah Dasar Negeri 005 Sibaruang Desa Sibaruang Kecamatan Siabu Kabupaten Mandailing Natal . Kurikulum yang diterapkan selama pengambilan data di SDN No.005 Sibaruang adalah Kurikulum Tingkat Satuan Pendidikan (KTSP). Kurikulum Tingkat Satuan Pendidikan (KTSP) merupakan sebuah kurikulum yang dibuat oleh sekolah yang melibatkan unsur kepala sekolah, pembantu kepala sekolah, guru, dan komite sekolah. Siswa-siswa SDN No.005 Sibaruang berasal dari daerah desa Siabaruang dan sekitarnya.

Umumnya siswa berasal dari keluarga yang orang tuanya berpropesi sebagai petani sawah dan ladang, orang tua sering melibatkan anaknya untuk membantu di sawah dan diladang, sehingga pokus anak untuk belajar sering pula terganggu. Kondisi ini berimplikasi pada pembelajaran, dimana sebagian besar siswa tampak kurang memperhatikan penjelasan dari guru, kurang memberikan respon terhadap pertanyaan dan penjelasan dari guru, siswa juga mengeluh terhadap tugas yang diberikan oleh guru, siswa tidak langsung mengerjakan tugas yang diberikan oleh guru, tidak tepat waktu dalam mengumpulkan tugas.

\section{Hasil Belajar Siswa Data Pretes (Uji awal)}

Untuk mengetahui kemampuan awal siswa dilakukan dengan tes kemampuan awal sebelum penerapan Model pendekatan Contextual Teaching and Learning. Tes kemampuan awal (tes kognitif) bertujuan untuk mengetahui seberapa besar kemampuan awal yang dimiliki siswa dalam memahami materi pada mata pelajaran PKn. Hasil tes kemampuan awal menunjukan rendahnya penguasaan materi siswa kelas V SDN No.005 Sibaruang data tersebut dapat dilihat pada Tabel 4.1

Tabel Distribusi hasil pretes

\begin{tabular}{|c|c|c|c|}
\hline Nilai & Frekuensi & $\begin{array}{c}\text { Rata- } \\
\text { trata }\end{array}$ & S.D \\
\hline 10 & 2 & \multirow{3}{*}{24} & \multirow{2}{*}{7,4} \\
\cline { 1 - 2 } 20 & 5 & & \\
\cline { 1 - 2 } 30 & 8 & & \\
\cline { 1 - 2 } Jumlah & 15 & & \\
\hline
\end{tabular}

Data pada Tabel 4.1. dirubah menjadi grafik histogram untuk memudahkan memprediski hasil belajar siswa, dapat dilihat pada gambar 4.1. 


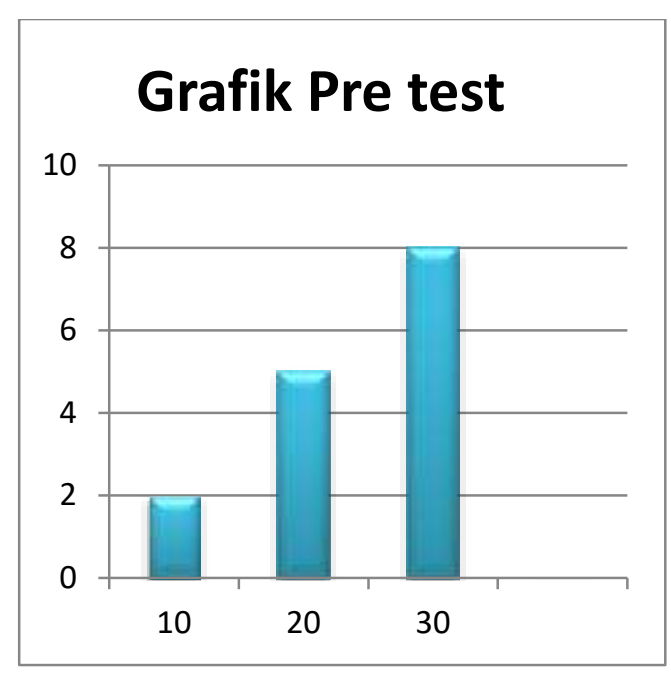

Gambar Grafik Data Pretes

Dari grafik 4.1 diatas dapat disimpulkan bahwa siswa tidak mempersiapkan diri sebelumnya dirumah untuk mengikuti materi baru berikutnya, sehingga penerapan siklus I perlu dialaksanakan.

\section{Data Postes I}

\section{Perencanaan}

Pada tahap ini peneliti membuat kegiatan perencanaan meliputi:

c) Penyusunan rencana pelaksanaan pembelajaran (RPP) dan lembar kegiatan siswa untuk KBM 1 dan KBM 2. Selanjutnya diubah atau ditambah sesuai dengan model pembelajaran Contextual Teaching and Learning (CTL).

d) Penyusunan instrumen penelitian berupa lembar observasi aktivitas siswa melalui penerapan model pembelajaran Contextual Teaching and Learning (CTL) dan tes pemahaman siswa.

\section{Pelaksanaan / Observasi}

Melaksanakan tindakan pembelajaran ke-1 dan ke-2 sesuai dengan RPP oleh peneliti sebagai guru PKn di kelas V SDN No.005 Sibaruang. Selama proses pembelajaran dilakukan observasi oleh observer (guru sejawat) untuk mengamati aktivitas siswa dan pengelolaan pembelajaran oleh guru. Diakhir siklus I dilakukan pula tes hasil belajar siswa untuk mengetahui pemahaman siswa sebagai formatif I. Hasil belajar yang diperoleh pada Siklus I selama dua pertemuan disajikan dalam Tabel 4.2.

Tabel Distribusi Data Postes 1

\begin{tabular}{|c|c|c|c|}
\hline Nilai & Frekuensi & $\begin{array}{c}\text { Rata- } \\
\text { rata }\end{array}$ & S.D \\
\hline 20 & 1 & \multirow{3}{*}{5} & \\
\cline { 1 - 2 } 40 & 5 & \multirow{3}{*}{23,2} \\
\hline 60 & 5 & & \\
\hline 80 & 2 & & \\
\hline 100 & 2 & & \\
\cline { 1 - 2 } Jumlah & 20 & & \\
\hline
\end{tabular}

Data Hasil belajar dalam tabel diatas dapat dilihat dalam diagram histogram seperti berikut:

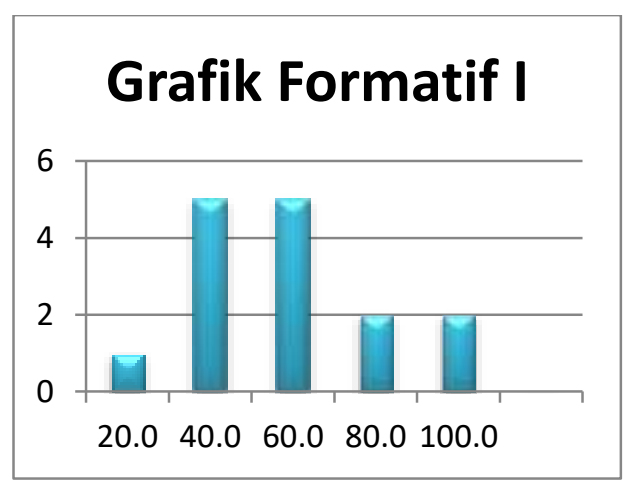

Gambar Grafik Data

Hasil Formatif I 
Pada setiap pembelajaran pertemuan 1 dan pertemuan 2 pada silus I, ketika peneliti melakukan proses pembelajaran peneliti berkolaborasi dengan dua orang pengamat (observer) untuk mengamati segala aktivitas siswa. Pengamat mengamati aktivitas siswa sesuai dengan lembar pengamatan yang sebelumnya telah disiapkan oleh peneliti selama 20 menit, dengan cara memberi ceklis setiap 2 menit sekali. Persentase pengamatan masing-masing observer pada pertemuan 1 dan pertemuan 2 ini adalah seperti pada tabel 4.3 berikut :

Tabel aktivitas belajar siswa siklus I

\begin{tabular}{|c|l|c|c|c|}
\hline \multirow{2}{*}{ No } & \multirow{2}{*}{ Aktivitas } & \multicolumn{3}{|c|}{ Siklus I } \\
\cline { 3 - 5 } & \multicolumn{1}{|c|}{ Jumlah } & Skor & Proporsi \\
\hline 1 & Menulis/membaca & 54 & 13.5 & $36 \%$ \\
\hline 2 & Mengerjakan & 33 & 8.25 & $22 \%$ \\
\hline 3 & $\begin{array}{l}\text { Bertanya pada } \\
\text { teman }\end{array}$ & 18 & 4.5 & $12 \%$ \\
\hline 4 & $\begin{array}{l}\text { Bertanya pada } \\
\text { guru }\end{array}$ & 19 & 4.75 & $13 \%$ \\
\hline 5 & $\begin{array}{l}\text { Yang tidak } \\
\text { relevan dengan } \\
\text { KBM }\end{array}$ & 26 & 6.5 & $17 \%$ \\
\hline & JUMLAH & 150 & 37.5 & $100 \%$ \\
\hline
\end{tabular}

\section{Refleksi}

Penerapan model pembelajaran Contextual Teaching and Learning (CTL) pada pembelajaran PKn siklus I belum sepenuhnya dapat meningkatkan hasil belajar siswa. Hasil belajar pada siklus I rata-rata 58,6 nilai terendah 20 dan nilai tertinggi 100. Siswa yang tuntas belajar menurut batas KKM 4 orang sedangkan 11 orang lainnya masih belum tuntas. Hal ini terjadi disebabkan oleh beberapa faktor diantaranya :

1. Model pembelajaran Contextual Teaching and Learning (CTL) yang diterapkan guru, merupakan bentuk belajar yang baru bagi siswa

2. Dalam pelaksanaan proses pembelajaran masih ada siswa yang bermain-main dan bercerita dengan teman, masih sedikit siswa yang nampak aktif.

3. Siswa belum terbiasa belajar dalam kelompok

4. Siswa malu-malu bertanya

Berdasarkan refleksi pada pembelajaran pertemuan 1 dan pertemuan 2, dan analisis hasil belajar siklus I maka perlu ada perbaikan pembelajaran berikutnya pada siklus II.

\section{Data Postes II \\ Perencanaan}

Berdasarkan hasil refleksi terhadap proses pembelajaran pada siklus I maka pada siklus II disusun skenario model pembelajaran Contextual Teaching and Learning $(C T L)$ dengan revisi tindakan untuk memperbaiki proses. Peneliti berdiskusi secara kolaboratif dengan rekan guru kelas sejenis dengan kegiatan perencanaan meliputi:

a) Penyusunan rencana pelaksanaan pembelajaran dan lembar kegiatan siswa.

b) Penyusunan instrumen penelitian berupa lembar observasi aktivitas siswa serta pengelolaan guru 
terhadap proses pembelajaran dengan menerapkan model pembelajaran Contextual Teaching and Learning (CTL) dan tes pemahaman siswa dalam kegiatan pembelajaran

\section{Pelaksanaan / observasi}

$$
\text { Melaksanakan tindakan }
$$

pembelajaran ke-3 dan ke-4 sesuai dengan RPP strategi Contextual Teaching and Learning(CTL) oleh peneliti sebagai guru PKn di Kelas V SDN No.005 Sibaruang. Selama proses pembelajaran dilakukan observasi oleh observer (guru sejawat) untuk mengamati aktivitas siswa. Diakhir siklus II dilakukan pula tes hasil belajar untuk mengetahui pemahaman kognitif siswa sebagai formatif II.

Setelah melakukan beberapa tindakan perbaikan pembelajaran pada Siklus II maka dilakukan tes pada Siklus II sebagai Postes II. Data Postes II disajikan dalam Tabel 4.4.

Tabel Distribusi Data Postes II

\begin{tabular}{|c|c|c|c|}
\hline Nilai & Frekuensi & $\begin{array}{c}\text { Rata- } \\
\text { rata }\end{array}$ & S.D \\
\hline 60 & 2 & \multirow{3}{*}{85,3} & \multirow{2}{*}{14,07} \\
\hline 80 & 7 & & \\
\cline { 1 - 2 } 100 & 6 & & \\
\cline { 1 - 2 } Jumlah & 15 & & \\
\hline
\end{tabular}

Merujuk pada Tabel 4.4, nilai terendah untuk Postes II adalah 60 dan tertinggi adalah 100 dengan 2 orang nilai dibawah kriteria ketuntasan. Nilai ini berada di atas kriteria keberhasilan sehingga dapat dikatakan KBM Siklus II telah berhasil memberi ketuntasan belajar pada siswa dalam kelas. Nilai ratarata kelas adalah 85,0 dengan standar deviasi 14,07 .

Data hasil potes II ini dapat disajikan kembali dalam bentuk grafik histogram, seperti pada Tabel 4.3 .

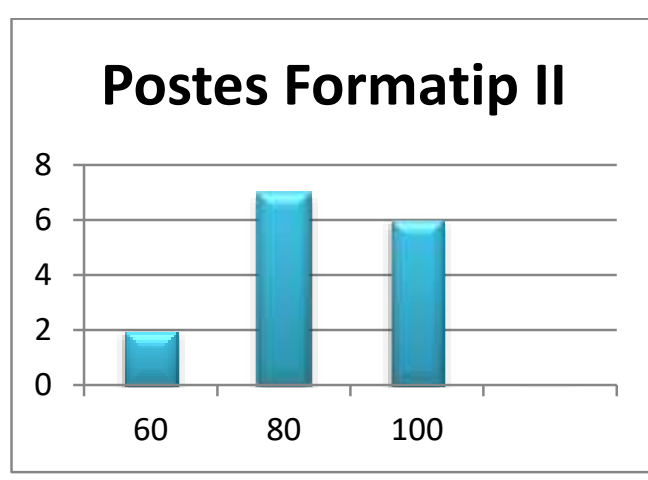

Gambar Grafik Data Hasil Formatif II

Merujuk pada tabel hasil tes yang telah dipaparkan sebelumnya, dapat dilihat nilai rata-rata tes siswa sebelum diterapakan model pembelajaran Contextual Teaching and Learning adalah 24, dan setelah diterapkan model pembelajaran Contextual Teaching and Learning meningkat menjadi 58,6 pada siklus I dan 85,3 pada siklus II.

Peningkatan hasil tes siswa dapat dilihat melaui tabel dan histogram berikut: 
Tabel Rekapitulasi Pretes, Postes I dan Postes II.

\begin{tabular}{|c|c|c|c|c|}
\hline No & Hasil Tes & $\begin{array}{c}\text { Data } \\
\text { Awal }\end{array}$ & Siklus I & Siklus II \\
\hline 1. & $\begin{array}{c}\text { Nilai } \\
\text { Tertinggi }\end{array}$ & 30 & 100 & 100 \\
\hline 2. & $\begin{array}{c}\text { Nilai } \\
\text { terendah }\end{array}$ & 10 & 20 & 60 \\
\hline 3. & $\begin{array}{c}\text { Rata-rata } \\
\text { nilai tes }\end{array}$ & 24 & 58,66 & 85,33 \\
\hline 4. & $\begin{array}{c}\text { Ketuntasan } \\
\text { klasikal }\end{array}$ & $0 \%$ & $26,66 \%$ & $86,66 \%$ \\
\hline
\end{tabular}

Data pada Tabel 4.5 dapat dituliskan kembali dalam histogram seperti Gambar 4.4 berikut:

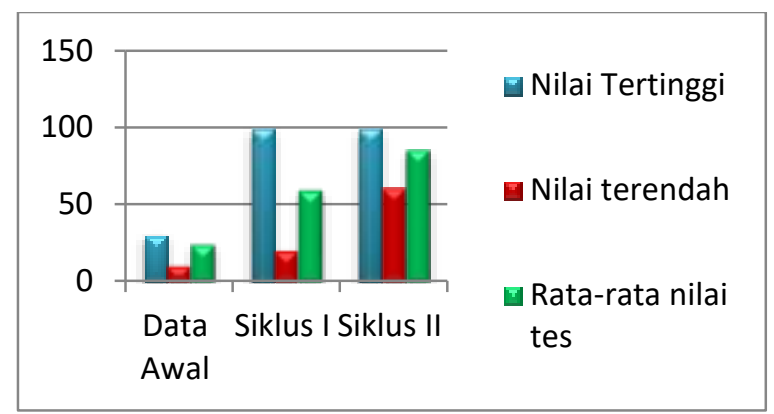

Gambar Grafik Hasil Belajar Kognitif

Pada setiap pembelajaran pertemuan 3 dan pertemuan 4 pada silus II, ketika peneliti melakukan proses pembelajaran peneliti berkolaborasi dengan dua orang pengamat (observer) untuk mengamati segala aktivitas siswa. Pengamat mengamati aktivitas siswa sesuai dengan lembar pengamatan yang sebelumnya telah disiapkan oleh peneliti. Pengamatan masingmasing observer pada pertemuan 3 dan pertemuan 4 ini adalah seperti pada tabel 4.6 berikut :
Tabel Rekapitulasi aktivitas siswa

\begin{tabular}{|c|c|c|c|c|}
\hline \multirow{2}{*}{ No } & \multirow{2}{*}{ Aktivitas } & \multicolumn{3}{|c|}{ Siklus II } \\
\hline & & Jumlah & Skor & Proporsi \\
\hline 1 & Menulis/membaca & 38 & 9.5 & $25 \%$ \\
\hline 2 & Mengerjakan & 55 & 13.75 & $37 \%$ \\
\hline 3 & $\begin{array}{l}\text { Bertanya pada } \\
\text { teman }\end{array}$ & 34 & 8.5 & $23 \%$ \\
\hline 4 & $\begin{array}{l}\text { Bertanya pada } \\
\text { guru }\end{array}$ & 15 & 3.75 & $10 \%$ \\
\hline 5 & $\begin{array}{l}\text { Yang tidak relevan } \\
\text { dengan KBM }\end{array}$ & 8 & 2 & $5 \%$ \\
\hline & JUMLAH & 150 & 37.5 & $100 \%$ \\
\hline
\end{tabular}

\section{Refleksi}

Penerapan model pembelajaran Contextual Teaching and Learning (CTL) pada pembelajaran PKn siklus II telah dapat meningkatkan hasil belajar siswa. Hasil belajar pada siklus II rata-rata 85,33 nilai terendah 60 dan nilai tertinggi 100 . Siswa yang tuntas belajar menurut batas KKM 13 orang, hanya 2 orang siswa yang masih belum tuntas. Namun ketuntasan kelas telah melampaui batas minimal $>85 \%$ yaitu sebesar $86,66 \%$. Dengan demikian hasil ini dapat dianggap bahwa pembelajaran dengan model pembelajaran Contextual Teaching and Learning $(C T L)$ telah dapat meningkatkan hasil belajar siswa dan tidak perlu lagi dilanjutkan pada siklus berikutnya. Keberhasilan pembelajaran pada siklus ini sesuai dengan perbaikan :

1. Siswa mulai terbiasa dengan model pembelajaran Contextual Teaching and Learning (CTL) yang diterapkan guru 
2. Dalam pelaksanaan proses pembelajaran siswa sudah mulai aktif

3. Siswa mulai terbiasa belajar dalam kelompok

4. Siswa mulai terbiasa bertanya baik pada teman ataupun pada guru

\section{Pembahasan}

\section{Setelah}

dilakukan

pembelajaran yang berimplementasi

kurikulum Tingkat Satuan

Pendidikan dengan model

pembelajaran Contextual Teaching and Learning, diperoleh perubahan baik suasana kelas maupun kemampuan siswa dalam menyelesaikan LKS dan tes hasil belajar, hal ini dikarenakan dalam setiap proses pembelajaran yang dilakukan dalam penelitian ini mencakup komponen-komponen yang terdapat dalam $C T L$, yaitu konstruktivisme, inquiry, questioning, learning comunity, modelling, reflection, dan authentic assessment.

Pada pertemuan pertama antusiasme siswa mengikuti proses pembelajaran di awal belum begitu baik, karena siswa merasa CTL merupakan sesuatu yang baru bagi mereka, terutama pada bagian modelling serta konstruktivisme dan inquiry yang diwujudkan dalam LKS. Antusiasme siswa diketahui pula melalui hasil pengamatan pada saat siswa melakukan reflection di akhir pembelajaran.

Melalui learning comunity siswa menjadi lebih bersemangat dalam mengikuti proses belajar. Pada Siklus I siswa tampak masih canggung dan bingung mengikuti alur pembelajaran. Untuk mengatasi kebingungan siswa dan memicu partisipasi seluruh siswa serta agar siswa tidak jenuh sekaligus untuk melihat kemajuan kemampuan siswa melengkapi LKS maka komunitas belajar pada Siklus II perlu dipersempit lagi.

Merujuk pada Tabel 4.4. Setelah menganalisis hasil belajar siswa pada mata pelajaran PKn dalam menyelesaikan tes akhir Siklus, diperoleh rata-rata nilai siswa pada Siklus I adalah 58,66 dengan jumlah siswa yang tuntas atau mencapai nilai 70 adalah 4 siswa atau 26,66 \% dari 15 siswa. Berdasarkan pekerjaan siswa pada Siklus I masih ditemukan beberapa penyelesaian yang kurang teliti. Menanggapi hal ini maka guru mengungkapkan kembali kesalahan pengerjaan tersebut pada saat melakukan apersepsi di Siklus II.

Pada Siklus II rata-rata nilai tes yang diperoleh siswa jauh lebih baik dari pada Siklus I, yaitu 85,3 dan persentase ketuntasan kelas mencapai $86,6 \%$, yaitu 13 siswa mendapatkan nilai $\geq 70$.

Melihat perkembangan dari pretes, akhir Siklus I sampai II pada mata pelajaran PKn terlihat adanya peningkatan rata-rata nilai tes hasil belajar. Walaupun ketuntasan kelas pada Siklus I belum tercapai, namun pada Siklus II menunjukkan hasil yang diharapkan, rata-rata nilai siswa 
melampaui skor minimal ketuntasan belajar 70 dan ketuntasan kelas mencapai $86,6 \%$.

Demikian pula dengan hasil belajar sudah mengalami peningkatan serta sudah mencapai indikator secara keseluruhan dari hasil pembahasan di atas dapat diketahui hal-hal sebagai berikut.

1. Hasil penilaian terhadap LKS dari setiap Siklus menunjukkan meningkatnya kemampuan siswa dalam melengkapi LKS.

2. Dari Siklus I sampai Siklus II tampak bahwa rata-rata nilai tes siswa semakin menunjukkan hasil yang lebih baik, dan indikator keberhasilan terlampaui pada Siklus II dalam waktu sesuai rancangan penelitian.

3. Model pembelajaran memberikan dampak positif terhadap tumbuhnya sikap konstruktif siswa, dimana sikap menyukai, keingintahuan dan saling membantu dalam masyarakat belajar pada pelajaran PKn semuanya dalam kategori sangat tinggi.

Sebagaimana diuraikan di atas dapat disimpulkan melalui dua Siklus yang dilakukan, penelitian ini mampu memberikan pencapaian kompetensi dasar yang meliputi kemampuan siswa melengkapi LKS, hasil belajar dalam pembelajaran materi PKn meningkat.

\section{KESIMPULAN}

1. Hasil belajar siswa dengan menerapkan Model Pembelajaran Contextual Teaching and Learning pada mata pelajaran PKn di kelas V SDN No. 005 Sibaruang tahun pembelajaran 2013/2014, diketahui sebelum pembelajaran rata-rata 24 dengan ketuntasan klasikal 0\%, pada Postes I diketahui rata-rata 58,66 dengan ketuntasan klasikal 26,66\%, dan Postes II hasil meningkat dengan nilai rata-rata 85,3 dengan ketuntasan klasikal 86,66\%.

2. Aktivitas belajar siswa dengan menerapkan model pembelajaran Contextual Teaching and Learning pada siklus I dan siklus II berdasarkan pengamatan kedua observer adalah : Pengamatan siklus I, menulis/membaca $36 \%$, bekerja $22 \%$, bertanya pada teman $12 \%$, bertanya pada guru $13 \%$, dan yang tidak relepan dengan KBM 17\%. Pengamatan siklus II, menulis/membaca $25 \%$, bekerja $37 \%$, bertanya pada teman $23 \%$, bertanya pada guru $10 \%$, dan yang tidak relepan dengan KBM 5\%.

Setelah melakukan kegiatan pembelajaran peneliti menyarankan agar Penggunaaan Model pembelajaran Contextual Teaching and Learning di SDN No.005 Sibaruang dapat menjadi pilihan medel pembelajaran untuk guru-guru khususnya guru-guru SDN No.005 Sibaruang dalam pembelajaran PKn. 
Model pembelajaran Contextual Teaching and Learning dapat diterapkan dengan sempurna dalam kelompok.

1. Selama kerja kelompok aturanaturan di informasikan kepada siswa sesuai dengan tujuan pembelajaran,

2. Motivasi diberikan pada awal pertemuan agar selama bekerja dalam kelompok aktivitas siswa lebih baik.

3. Model belajar CTL dapat digunakan sebagai salah satu alternatif model yang digunakan guru-guru di SDN No.005 Sibaruang.

\section{DAFTAR RUJUKAN}

Arikunto,S. (1992). Prosedur

Penelitian Suatu

Pendekatan Praktek.

Jakarta: Rineka Cipta.

Aqib, Zainal. (2006). Penelitian Tindakan Kelas. Bandung: Yrama Widya.

Hamalik, Oemar. 1995. Kurikulum dan Pembelajaran. Jakarta: Bumi Aksara.

Nasution. 1995. Didaktik Asas-asas Mengajar. Jakarta: Bumi Akasara.

Sugandi, Achmad \& Haryanto. 2004. Teori Pembelajaran. Semarang: UPT MKK UNNES.

Syah, Muhibbin. 1995. Psikologi Pendidikan dengan Pendekatan Baru. Bandung: Remaja Rosdakarya.
Widihastuti, S \& Rahyuningsih, F. 2008. Pendidikan Kewarganegaraan Untuk SD Kelas V. Jakarta: Pusat Perbukuan. 